\title{
Language Learning Strategies and Academic Success: a Mexican Perspective*
}

\author{
Estrategias de aprendizaje de lenguaje y éxito \\ académico: una perspectiva mexicana
}

Recibido: septiembre 22 de 2011 | Revisado: febrero 19 de 2013 | Aceptado: agosto 19 de 2013

\author{
Martha Catalina Del Ángel Castillo** \\ Tecnológico de Monterrey, Monterrey Campus, México \\ Katherina Edith Gallardo Córdova *** \\ Universidad TecVirtual, México
}

doi:10.11144/Javeriana.UPSY13-2.11sa

Para citar este artículo: Del Ángel, M. C., \& Gallardo, K. E. (2014). Language learning strategies and academic success: A Mexican perspective. Universitas Psychologica, 13(2), 703-713. doi:10.11144/ Javeriana.UPSY13-2.11sa

* Acknowledgments: We gratefully acknowledge all of the wonderful help and support provided by the following people: Tecnologico de Monterrey administrators, for providing the academic context and resources in carrying out this research; English teachers of the Modern Language Department, for their precious class time for data collection; and participants of the study, for having shared their information and experiences.

** Coordinadora del Programa de Inglés. Departamento de Lenguas Modernas. Tecnológico de Monterrey, Monterrey Campus, México. E-mail: marthadelangel@itesm.mx

**** Directora de la Escuela de Graduados en Educación. Tecnológico de Monterrey, Universidad TecVirtual. Web: http://itesm.academia.edu/KatherinaGallardo,E-mail: katherina.gallardo@tecvirtual.mx

\section{A B S T R A C T}

The authors' goal is to explore the language learning strategies most frequently used by academically successful students in higher education. As language learning strategies is a field that needs to be deeply explored, Mixed Method Design was selected. This study was performed in three phases: (i) quantitative: it describes the results after analyzing a population of 1283 students who answered a general questionnaire and The Strategy Inventory for Language Learning (Oxford, 1990). (ii) qualitative: it describes how a sample was selected as a result of phase I and how the interviews were held. (iii) interpretation: it combines the previous stages. The results revealed that language learning strategies along with other personal and family complements lead students to reach academic success.

Keywords authors

Learning strategies, second language, education.

\section{Resumen}

El objetivo de los autores es explorar las estrategias de aprendizaje de idiomas más utilizados por los estudiantes académicamente exitosos en la educación superior. Como las estrategias de aprendizaje de idiomas es un campo que necesita ser estudiado profundamente, se seleccionó un diseño de investigación mixto. Este estudio se realizó en tres fases: (i) cuantitativa: describe los resultados después de analizar una población de 1.283 estudiantes que contestaron un cuestionario general y el inventario Estrategia para el aprendizaje de idiomas (Oxford, 1990); (ii) cualitativa: describe cómo se seleccionó una muestra como resultado de la fase I y cómo se llevaron a cabo las entrevistas; (iii) la interpretación: combina las etapas anteriores. Los resultados revelaron que las estrategias de aprendizaje de idiomas junto con complementos personales como la familia conduce a los estudiantes a alcanzar el éxito académico.

Palabras clave

Estrategias de aprendizaje, segunda lengua, educación. 


\section{Introduction}

Educational systems in Latin-American countries have been transforming constantly due to economic factors such as competitiveness and globalization, which have become worldwide conditions for development. Acquiring bilingual competencies is considered nowadays a primary resource for undergraduate students. For this reason, most higher education curricula include or demand English to be learned for professional purposes. Haugen (1972) stated that "necessity is the mother of bilingualism" because most people use two languages in order to function as a productive person, according to their social circumstances, job opportunities or intellectual needs. Thus, teaching and learning English as a second language in Latin-American universities is no longer a complement but a crucial discipline. Mexico is not an exception.

The focus of this research is the learning process viewed as a set of specific skills that students develop through different experiences which put them in contact with a second language. Academically successful students as ideal participants for studying Language Learning Strategies are able to analyze, synthesize, and evaluate information; communicate effectively with others; are capable of working collaboratively in culturally diverse settings, are self-motivated; make their own decisions and solve problems among other features and behaviors (Brockman \& Russell, 2007). Obtaining a profile of successful learner's features where second language learning process is integrated could bring information to improve teaching decisions. Brockman and Russell's study has its origins on a research directed by Oxford (1990) in which she proposed the use of the Strategy Inventory for Language Learning (SILL). This instrument has been recognized as a new way to measure Language Learning Strategies considering the four language skills (listening, speaking, reading and writing).

The research presented in this article tried to answer two questions around Language Learning Strategies development in higher education contexts where English is the target language to be learned:
- What are the Language Learning Strategies most frequently used by students?

- What are the main characteristics of academically successful students in English performance and in other disciplines?

Currently, English-Spanish bilingualism has become essential for Latin-Americans for economic and cultural reasons. At a glance, some statistics about English usage reveal that 1,400 million people live in countries where English has official status. One out of five of the world's population speaks English to some level of competence. It is the global language of music, books, newspapers, airports, trading and business, conferences, technology, diplomacy, and publicity; therefore, becoming bilingual (Spanish- English) is no longer an option but rather a must (Graddol, 2000).

Within the English learning process, there have been different terms to refer to the abilities that an individual develops when learning a second language. Concepts like language skills, language proficiency, language achievement, language competence, and language performance are among the most common (Baker \& Jones, 1998). Among these concepts, there is one devoted to language strategies which are defined as "the special thoughts or behaviors that individuals use to help them comprehend, learn, or retain new information" (O’Malley \& Chamot, 1990, p. 1) a set of different actions performed by the language learner to improve his/ her learning process or perform better in a certain situation where this second language is needed (Cohen, 1998). Additionally, Chamot (2004) states that learners need to explore different learning strategies such as metacognitive strategies so that, they can be able to plan, monitor, and evaluate themselves throughout their learning efforts. Language Learning Strategies of all kinds are more frequently used by higher education students (Griffiths, 2004; O’Malley \& Chamot, 1990).

According to Griffiths (2004) one of the difficulties with researching Language Learning Strategies is that they cannot generally be observed directly; they can only be inferred from language learner behavior. Oxford designed an instrument 
called Strategy Inventory for Language Learning (SILL) which was based on a strategy system and was enriched by additional items from early surveys conducted by O'Malley, Chamot and Rubin (O’Malley \& Chamot, 1990; Oxford, 1990). It has been proved through several research works that English learners who were more proficient and more motivated consistently reported on the SILL that they used a wider range of strategies, and used them more frequently, than did learners who were less proficient and less motivated. As a matter of fact, versions of the SILL have been used with groups of foreign language learners in high schools, universities, as well as at the Defense Language Institute, The Foreign Service Institute, and the Peace Corps/Philippines. Adult English learners in several countries have also been applied the SILL. For such a reason, it has been translated into several languages such as Chinese, Japanese, and Spanish. Its concurrent validity comes from a Foreign Service Institute study made with 80 adults; the results showed that adults who use more strategies were more highly skilled than those who used fewer strategies (Oxford, 1990). In other words, the more strategies learners use the more language proficient they tend to be.

The SILL instrument was used with Taiwanese college students in a study which evaluated one-semester-long English learning strategy training course considering its impact on student's learning achievement, attitudes, anxiety, and proficiency. Besides the SILL, students were tested on the Test of English as a Foreign Language, the Motivational Intensity Questionnaire and the Foreign Language Classroom Anxiety Scale. Results supported the fact that language-learning strategies can be taught and can help foreign language learners in the learning process (Huang, 2001). Considering that Language Learning Strategies help students on their learning process; then, knowing which learning strategies students use more frequently will allow the researchers to find out which of them are more frequently practiced by academic successful students.

The SILL was also used with Arabic -speaking English-majors at the An-Najah National Univer- sity in Palestine. This study reports on the current English Language Learning Strategies used by a sample of 99 male and female students at a B.A. degree. The results showed that these students used learning strategies with high to medium frequency, and the highest rank (79.6\%) was for metacognitive strategies while the lowest (63\%) was for compensation strategies. Besides, gender and proficiency had no significant differences in the use of strategies (Abu, 2003). The SILL has been used to find out what strategies are used by language proficient students at a university level.

Similarly, there have been some studies on language strategies frequency use in Latin-America; particularly, in Mexico, Arellano (1999) applied the Oxford's instrument designed to apply two of the learning strategies listed: 1) use flashcards to remember new words and 2) reading in English. The participants were first level English learners and the main objective was to prove the usefulness of these strategies (Arellano, 1999; Oxford, 1990). The results showed that the use of learning strategies helped students achieve a better performance in the English learning. Later, Sheorey (2008) made a research on Language Learning Beliefs and Learning Strategies of Mexican EFL students concluding that even though students are motivated to learn English, they believe that language learning is a question of memorization, including memorizing grammar rules also, "repeat and practice".

\section{Methods and Materials}

Even if Language Learning Strategies have been studied for more than four decades, for the Latin-American context it is quite a new topic and Mexico is an example. The studies conducted by Arellano (1999) and Sheorey (2008) left a first contribution in this field in the Mexican community. Nevertheless, a deeper way for studying Language Learning Strategies was needed to find out more details - beyond beliefs- about English for Foreign Language learners. Considering these needs, it was decided to select the Mixed-Methods approach as this opens multiple research advantages: (1) it might answer questions that other methodologies cannot 
because of the possibility to mix up data, (2) it provides the possibility to get better and stronger inferences and (3) it gives the opportunity for presenting a greater variety from divergent views. (Erzberger \& Kelle, 2003). In short, when using Mixed-Methods, the researchers are able to use more varied data that will allow them to analyze the social phenomena considering different perspectives that can lead to discover new knowledge.

This study was held in Tecnologico de Monterrey, a private non-profit university that counts with 33 campi and headquarters in the United States, South America and the Caribbean, Europe and Asia. This research was conducted in Campus Monterrey (Northern Mexico) which offers an English Program along the first six semesters for all the students registered. The participants were students who took an English class between January and May 2009 (one semester). The total population was 1,283 students. The description of the research processes, formed by three phases is next described:

Phase 1: It consisted on the application of SILL (version \#7) for English Foreign Language learners. It was applied to 1,283 students. After the application results from the 266 academically successful students were analyzed separately. For this study the researcher counted on the authorization of Dr. Oxford for the use and adaptation of her instrument if needed. It is convenient to mention that, regarding the context of the scenario (Mexican community) SILL was translated into Spanish to facilitate students to respond the questions in their mother tongue. This instrument uses a 5 - point Likert scale (5 always; 4 frequently; 3 occasionally; 2 rarely; and 1 never or almost never). It contains 50 items that measure six groups of strategies: memory, cognitive, compensation, metacognitive, affective and social.

For processing data purposes, some codes were given to each group, set and item. This coding system for SILL is shown on Table 1.

Phase 2: In this second phase a questionnaire was applied. This instrument asks students to report their academic routines and achievements related to: family context and parent-students relationship, use of the English language in non-academic situations and their performance on extra-academic activities. Specifically, the questionnaire consisted on two sections: Section I includes 11 questions related to students general data (name, registration number, major, course level, gender,

TABLE 1

Coding for Questions Corresponding to Each Language Learning Strategy

\begin{tabular}{|c|c|c|}
\hline Groups & Sets of strategies & Items \\
\hline Memory & $\begin{array}{l}\text { 1. Creating mental linkages. } \\
\text { 2. Applying images and sounds. } \\
\text { 3. Reviewing well. } \\
\text { 4. Employing action. }\end{array}$ & A1-A9 \\
\hline Cognitive & $\begin{array}{l}\text { 5. Practicing. } \\
\text { 6. Receiving and sending messages. } \\
\text { 7. Analyzing and reasoning. } \\
\text { 8. Creating Structure for input and output. }\end{array}$ & B10-B23 \\
\hline Compensation & $\begin{array}{l}\text { 9. Guessing intelligently. } \\
\text { 10. Overcoming limitations in speaking and writing. }\end{array}$ & $\mathrm{C} 24-\mathrm{C} 29$ \\
\hline Metacognitive & $\begin{array}{l}\text { 11. Centering your learning } \\
\text { 12. Arranging and planning your learning } \\
\text { 13. Evaluating your learning }\end{array}$ & D30-D38 \\
\hline Affective & $\begin{array}{l}\text { 14. Lowering your anxiety } \\
\text { 15. Encouraging yourself } \\
\text { 16. Taking your emotional temperature }\end{array}$ & E39-E44 \\
\hline Social & $\begin{array}{l}\text { 17. Asking questions } \\
\text { 18. Cooperating with others } \\
\text { 19. Empathizing with others }\end{array}$ & F45-F50 \\
\hline
\end{tabular}

Source: own work 
birth date, geographical origin, semester, general grade average both in the English Course and in other subjects of their majors). Section II includes 8 questions related to how often students practice certain actions such as sharing their worries, problems, and hopes with their parents (one of them, or both), searching to be aware of what is happening in their environment and community, having participated in extra-curricular activities (sports, cultural, school groups), finding ways to solve difficulties on their own, having proposed him/herself as the leader for assignments or teamwork, doing their homework completely (projects, presentations, exercises), doing their homework on time (projects, presentations, exercises), putting ecological actions into practice, and using the English Language in non-academic contexts (with foreigners, singing/ listening to songs, reading magazines, watching TV or movies).The same 1,283 students filled out this instrument. The questionnaire structure is shown in Table 2.

Phase 3: From the 1,283 English learners, it was necessary to identify academically successful students for comparison purposes (Brockman \& Russell, 2007; Oxford, 1990). Their average grade was considered between 91 and 100 at that mo- ment. It is important to clarify that the Mexican grade scale goes between 0 as the minimum score and 100 as the maximum one. This phase consisted on the application of a semi-structured, in depth interview. 15 base-questions were asked about leadership at school, extra-curricular activities, professional practice, academic grades, time dedicated to study, career identity, clear objectives, jobs related to their career, family structure and family income. From the invitation sent to the 266 academically successful students, 10 ( 5 male and 5 female) were able to participate. The interviews were recorded and transcribed verbatim for analysis.

\section{Results}

The results of this study are reported according to the three research phases previously explained. For Phase 1, two tables showing adaptations and main results from the application of SILL are commented. For Phase 2, results from the questionnaire about students' behaviors and attitudes towards learning are described. Finally, illustrative quotes collected during interviews in Phase 3 are shown into one table. As this instrument was applied in a Mexican context, it was necessary to translate it to Spanish (see Table 4).

TABLE 2

Topics Considered for the Questionnaire

\begin{tabular}{|c|c|c|}
\hline Topic & Evaluating aspects & Item \# \\
\hline General Data & $\begin{array}{l}11 \text { questions related to students general data (name, number, major, } \\
\text { course level, gender, birth date, geographical origin, semester, general } \\
\text { grade point average both in the English Course and in other subjects of } \\
\text { their majors). }\end{array}$ & $1-11$ \\
\hline Parents & $\begin{array}{l}\text { Sharing worries, problems, and hopes with their parents (one of them, } \\
\text { or both). }\end{array}$ & 12 \\
\hline Environment and community & $\begin{array}{l}\text { Searching to be aware of what is happening in their environment and } \\
\text { community }\end{array}$ & 13 \\
\hline Extra-academic activities & $\begin{array}{l}\text { Participating in extra-curricular activities (sports, cultural, school } \\
\text { groups). }\end{array}$ & 14 \\
\hline Self-dependency & Finding ways to solve difficulties on their own & 15 \\
\hline Leadership & Proposing oneself as the leader for assignments or teamwork & 16 \\
\hline Commitment and responsibilities & $\begin{array}{l}\text { Doing homework completely and on the time requested (projects, oral } \\
\text { presentations, exercises). }\end{array}$ & $17 \& 18$ \\
\hline Ecological consciousness & Putting ecological actions into practice & 19 \\
\hline $\begin{array}{l}\text { English language in everyday } \\
\text { situations }\end{array}$ & $\begin{array}{l}\text { Using the English Language in non-academic contexts (with foreigners, } \\
\text { singing/listening to songs, reading magazines, watching TV or movies }\end{array}$ & 20 \\
\hline
\end{tabular}

Source: own work 
TABLE 3

Topics Considered for the Semi-Structured Interview

\begin{tabular}{ll}
\hline \multicolumn{1}{c}{ Main topics } & \multicolumn{1}{c}{ Specific questions } \\
\hline 1.Academic Leadership & $\begin{array}{l}\text { Have you been a leader of a students' association? } \\
\text { Which one? }\end{array}$ \\
2. Extra-curricular activities & $\begin{array}{l}\text { Have you participated in extra-curricular activities (cultural, academic, ecological, } \\
\text { social, or sport)? }\end{array}$ \\
3. Professional practice & $\begin{array}{l}\text { How do you see yourself in the future in your profession? Working on your own or for a } \\
\text { company? }\end{array}$ \\
4. Academic grades & What grades have you obtained through your career? \\
5. Time dedicated & How long do you study or do homework assignments? \\
6. Career identity & Do you know what you would like to achieve with your career? \\
7. Clear objectives & $\begin{array}{l}\text { Are you planning to study a master degree? Do you plan to study abroad? Have you had } \\
\text { an international experience? }\end{array}$ \\
8. Job related to his career. & Have you had any job related to your career? \\
9. Family structure & How is your family structure? Father, mother, siblings? \\
10. Family income & Has your family provided you with the economic resources for your education? Who \\
\end{tabular}

Source: own work

TABLE 4

A Sample of How SILL Was Translated (Part A: Memory Strategies)

\begin{tabular}{|c|c|}
\hline English & Spanish \\
\hline Part A & Sección A \\
\hline $\begin{array}{l}\text { I think of relationships between what I already know and new } \\
\text { things I learn in English. }\end{array}$ & ya conozco y \\
\hline in a sentence so I can remember them. & $\begin{array}{l}\text { las. } \\
\text { las palabras en inglés en una oración para poder re- }\end{array}$ \\
\hline $\begin{array}{l}\text { I connect the sour } \\
\text { picture of the wor }\end{array}$ & $\begin{array}{l}\text { o el sonido de una nueva palabra en inglés con una } \\
\text { dibujo de la palabra para que me ayude a recordarla }\end{array}$ \\
\hline I remember a new English word & $\begin{array}{l}\text { do una imagen } \\
\text { lizar. }\end{array}$ \\
\hline I us & para recordar palabras nuevas en inglés. \\
\hline I us & glés. \\
\hline nglish w & a actuación física de las palabras nuevas en inglés. \\
\hline I re & frecuencia las lecciones nuevas en inglés. \\
\hline I remember new English words or phrases by remembering their & Recuerdo palabras o frases nuevas mediante su ubicación en \\
\hline
\end{tabular}

Source: own work

Even if SILL was applied to the 1,283 students in Phase 1, it also became necessary to compare SILL results between the 266 academically successful students and those who are not classified as successful ones (1017 students). This comparison might confirm or reject the idea of having this kind of students as an ideal sample to study Language Learning Strategies (Oxford, 1990). Table 5 shows the results of these two groups in SILL application.
On one hand, results about SILL application revealed the frequency in which academically successful students use certain Language Learning Strategies versus what non-academically successful students do. A $T$ test was run in order to compare the results of these two samples assuming equal variances between both groups. The test showed that 11 out of 50 questions have a significant difference. From these 11 questions, four belong to Metacognitive strategy; four belong to Cognitive 
TABLE 5

Differences in SILL between Academically Successful and Non-Successful Students

\begin{tabular}{lcc}
\hline \multicolumn{1}{c}{ Strategies } & $\begin{array}{c}\text { Average punctuation academically } \\
\text { successful students }\end{array}$ & $\begin{array}{c}\text { Average punctuation non- } \\
\text { academically successful students }\end{array}$ \\
\hline Cognitive B & 3.49 & 3.16 \\
Metacognitive D & 3.65 & 3.54 \\
Affective E & 2.73 & 2.68 \\
Social F & 3.54 & 3.5 \\
Memory A & 2.92 & 2.88 \\
Compensation C & 3.19 & 3.41 \\
\hline
\end{tabular}

Source: own work

TABLE 6

Average and Reliability Coefficient Values for SILL

\begin{tabular}{lcc}
\hline \multicolumn{1}{c}{ Strategies } & Average punctuation & Reliability (Cronbach's alpha) \\
\hline Metacognitive D & 3.65 & 0.8 \\
Social F & 3.54 & 0.74 \\
Cognitive B & 3.49 & 0.78 \\
Compensation C & 3.19 & 0.63 \\
Memory A & 2.92 & 0.76 \\
Affective E & 2.73 & 0.66 \\
\hline
\end{tabular}

Note. Cronbach's alpha reliability coefficient higher than 0.7 is considered acceptable

Source: Hernández, Fernández, and Baptista (2006).

strategy, two belong to Memory strategy and only on to Affective.

On the other hand, results about SILL internal consistency showed that higher values of Cronbach's alpha relied on Metacognitive, Cognitive, Memory and Social Strategies: 0.8, 0.78, 0.76 and 0.74 respectively (see Table 5 ). All of these coefficients are considered highly acceptable (Hernández, Fernández, \& Baptista, 2006). Table 6 contains these results.

The questionnaire applied in Phase 2 and the interview applied in Phase 3, both, served as a complimentary way to go deeper to try to understand some other aspects that characterize academically successful student's profile. The SILL uses the same 5-point Likert scale (5 always; 4 frequently; 3 occasionally; 2 rarely; and 1 never or almost never). The questions in Instrument 2 asks students about commitment and responsibilities, self-dependency, environment and community, extra-academic activities, ecological consciousness, relationship with their parents, leadership, and use of English in everyday situations.

From the questionnaire topics, some of them punctuated quite high. This is the case of commitment and responsibilities that became one of the highest priorities in their academic tasks (4.63). Being punctual for homework and other activities is important as well (4.52). It is also relevant to reveal that their sense of self-dependency seems to be high for they search ways to solve problems on their own (4.56). About their use of English in non-academic contexts, these students assured that they use their English knowledge to communicate quiet frequently (4.15). Additionally, they share their worries, problems and hopes with their families (4.01).

Even though, some of the topics did not get higher scores as it was thought. For example, searching to be aware of what is happening in the environment or community is not that frequently practiced (3.97), nor is looking for opportunities to be a leader (3.97). These students neither are 
completely involved in extra- curriculum activities nor do they put ecological actions into practice as often (3.72).

Statistics obtained from the SILL data analysis and the questionnaire do not confirm that a significant difference exists between successful and non-successful students in this matter. This means that, in this particular case, the process of trying to find if there is any relationship between some characteristics of academic successfulness and the process of Language Learning Strategies Development was not possible to determine through this instrument.

Even if the results reported from SILL and the questionnaire were not significant to explain the difference while developing Language Learning Strategies between successful and non-successful students, the qualitative data obtained through the interviews helped understand deeply some practices that this kind of students perform to polish their Language Learning Strategies accurately (Brockman \& Russell, 2007; Oxford, 1990). Table 7 contains the most representative quotes from the ideas expressed by the 10 interviewees. These quotes have been already translated into English.

The instrument applied in Phase 3 helped the researchers upload complementary characteristics of academically successful students' profile what sometimes are neither well understood nor connected to the way students develop Language Learning Strategies (Brockman \& Russell, 2007; Oxford, 1990). All of the academically successful students selected for the interview have participated in extra-curricular activities such as playing instruments, practicing sports or dancing, doing some kind of social work in urban and rural areas, organizing international forums, and sometimes traveling abroad. Some of the interviewees have also had experiences as leaders in school committees since high school and have continued to do it in the university programs.

It is shown that most of the students consider academic grades, time dedicated as well as commitment and responsibility as the most important duties they have to perform. This matches to what some interviewees (P1 and P4) stated verbally. They considered studying hard and competition as keys to achieve academic success. This is also related to what $\mathrm{P} 1$ and $\mathrm{P} 10$ stated when confirming that anytime, anywhere is appropriate to start doing their homework assignments in order to get to do it on time and fully completed.

Students know what they want to achieve as professionals. Some of them have had previous experience by working in an area related to their career; such is the case of $\mathrm{P} 2$ who started to run his own business for four years and P8 who designed a system in a private company. Some students plan to work in a certain company like P7 who sees himself working in a car company or P10 who later would like to have his own business either alone or with a member of his family. They also have made inversions for the future such as studying abroad like P7 who spent a summer in Canada polishing his English or are planning to study overseas like P6 who is planning to apply for a leadership program because of his academic grades.

Family and communication play an important role too. For instance, P2 says that parents being always there have been a key to his success and their siblings. This is possible even if the family structure has changed. P5 shares his worries, illusions, with both of his parents even though one of them does not live in the same house. For $\mathrm{P} 3$ a problem in the family's economic situation has not been an obstacle for studying, scholarships have contributed to continue with her career or objectives.

Even though it is important to notice that academic successful students surround themselves with activities that enrich their learning environment and as a consequence, it seems these conditions open up their possibilities to strongly develop Language Learning Strategies.

\section{Discussion}

Within the number of design possibilities when using Mixed-Methods (Creswell, Plano, Gutmann, \& Hanson, 2003) the Sequential Explanatory Design was considered to fit this study's needs. This design uses the quantitative data as a priority. Considering this design framework, the 
TABLE 7

Quotes from Interviews

\begin{tabular}{|c|c|}
\hline Main topics & Student's quotes \\
\hline \multirow[t]{2}{*}{ 1.Academic Leadership } & $\begin{array}{l}\text { P9: "I participated in High School as a leader; as a matter of fact I started the leadership } \\
\text { school committee and began to organize congresses each semester, later on I started } \\
\text { coordinating other high schools to do the same. I finished high school and these } \\
\text { committees are still going on." }\end{array}$ \\
\hline & $\begin{array}{l}\text { P4: "I participated in high school in some school groups to get funds for food and } \\
\text { entertainment companies within the high school. I also participated organizing summer } \\
\text { camps for orphans and then in a health community service group." }\end{array}$ \\
\hline \multirow[t]{3}{*}{ 2. Extra-curricular activities } & P5: "I practice soccer in the university" \\
\hline & P8: "I traveled to Guadalajara, Mexico to save turtle’s eggs from hunters". \\
\hline & $\begin{array}{l}\text { P3: "I belong to the students group here in the university and have organized congresses } \\
\text { and forums". }\end{array}$ \\
\hline \multirow[t]{2}{*}{ 3. Professional practice } & $\begin{array}{l}\text { P3: "After graduating I would like to work in a company getting promotions and after } 10 \\
\text { or } 15 \text { years to get to have my own company". }\end{array}$ \\
\hline & $\begin{array}{l}\text { P6: "I want to study my career now and then a Master's Degree. I do not plan to get } \\
\text { married soon, I want to work for some time and save some money in order to establish a } \\
\text { business but being independent from what father has". }\end{array}$ \\
\hline \multirow[t]{2}{*}{ 4. Academic grades } & $\begin{array}{l}\text { P1: "I am very dedicated, responsible, obsessive and yet perfectionist. If I ever get an } 80 \text { I } \\
\text { say to myself that I can do higher I try to do my best in everything I do". }\end{array}$ \\
\hline & $\begin{array}{l}\text { P4: "The competition is a factor that influences in your academic achievement, for } \\
\text { instance if you see someone getting high grades you say: "Hey, I want to be there too". I } \\
\text { do not think competition as the most important but it does have an impact." }\end{array}$ \\
\hline \multirow[t]{2}{*}{ 5. Time dedicated } & $\begin{array}{l}\text { P10:" I do not wait to be at home or in a comfortable place to start doing my homework } \\
\text { assignments. I even do them in the hall". }\end{array}$ \\
\hline & $\begin{array}{l}\text { P1: "I think it is just a question of dedicating time for everything. For instance, to } \\
\text { dedicate, at least two hours (not the whole day) to do the homework assignments, but } \\
\text { doing them in a correct way not in a hurry because they are part of your total grade; } \\
\text { otherwise you will get very stressed. }\end{array}$ \\
\hline \multirow[t]{2}{*}{ 6. Career identity } & P7: "I see myself working in a car company and later on having my own company". \\
\hline & $\begin{array}{l}\text { P10: "I would like to have some professional practice in a company but later on I would } \\
\text { like to start a family business with my brother". }\end{array}$ \\
\hline \multirow[t]{2}{*}{ 7. Clear objectives } & P7: "I spent a summer in Canada to polish my English". \\
\hline & $\begin{array}{l}\text { P6: "I have not participated in an exchange program I do plan to do go to Berkeley, } \\
\text { U.S.A. which has an International Business Leadership Program in the summer whose } \\
\text { main requirement is to have high academic grades. }\end{array}$ \\
\hline \multirow[t]{2}{*}{ 8. Job related to his career. } & $\begin{array}{l}\text { P2: "I had a home delivery business for four years with my brother. We distributed cheese } \\
\text { and we were able to serve } 150 \text { customers". }\end{array}$ \\
\hline & $\begin{array}{l}\text { P8: "I worked in a project with one of my father's friends who has a company that } \\
\text { makes bottle and label machines where I designed a purchasing system in a PHP internet } \\
\text { language. That was my first job". }\end{array}$ \\
\hline \multirow[t]{2}{*}{ 9. Family structure } & $\begin{array}{l}\text { P2: "We are a family. My father works here at home; he has breakfast, lunch and dinner } \\
\text { with us. My mom is a housewife, she sometimes helps my dad in his business, she also } \\
\text { takes care of my sisters and I think this is part of what has made me successful because } \\
\text { we all (my sisters and I) have had success. }\end{array}$ \\
\hline & $\begin{array}{l}\text { P5:" Although my parents are divorced I have a great communication with my mom and } \\
\text { my dad even if I do not see him every day". }\end{array}$ \\
\hline \multirow[t]{2}{*}{ 10. Family income } & P9: "I won a scholarship sponsored by a company because of my high academic grades". \\
\hline & $\begin{array}{l}\text { P3: "I had a scholarship when we were living in the United States in a time when my } \\
\text { parents' financial situation was not good; so I told my parents to apply for a scholarship } \\
\text { because I had high academic grades". }\end{array}$ \\
\hline
\end{tabular}

Note. All of the interviewees answered to all the questions. This table contains just an extract of complete dialogues.

Source: own work 
data collected along this study was quantitative (through instruments 1 and 2: SILL and questionnaire) and qualitative through instrument 3 (interview). The quantitative analysis consisted in running some statistics for obtaining central and dispersion measurements, reliability coefficients (Cronbach's alpha), the null hypothesis to test that a sample comes from a normally distributed population (Shapiro and Wilk's Test) and to determine if there is a statistically significant difference in the two groups of students: academically successful and unsuccessful (T-test) (Hernández et al., 2006). Then, the qualitative one was used to support and understand deeply details about the findings of this topic that has been rarely studied in Latin-American contexts.

As in previous research of this matter in the past twenty years (Abu, 2003; Arellano, 1999; Huang \& Tsai, 2003; Oxford, 1990; Sheorey, 2008) the SILL results showed that the Language Learning Strategies most frequently used are Cognitive and Meta-cognitive Strategies. Cognitive strategies as they analyze, and synthesize and meta-cognitive as they plan and evaluate their own learning. The affective strategies which refer to emotions, attitudes, motivations, and values are the least used, that is to say, learners do not frequently gain control over affective strategies. These results are coherent to what we found in this study.

There is another point to highlight on this research: complementary phases ( 2 and 3 ) were made to reinforce or reject the hypothesis that academically successful students could be a better target population to study Language Learning Strategies profoundly (Brockman \& Russell, 2007; Oxford, 1990). The questionnaire and the interview allowed the researchers to study this phenomenon in a deeper way and led them to find out some actions that can be related to the way successful students learn and use English in certain situations. The comparison made for finding significant differences in some or all Language Learning Strategies revealed that the hypothesis of considering academically successful students a special group for understanding learning strategies and their use has been rejected in this context.
Even though statistics from SILL results do not support such a difference between groups of students in this scenario it is worthy to highlight that some other aspects that coexist in Language Learning Strategies such as cultural aspects are included. Previous studies carried on Mexico, Palestine, and China (Abu, 2003; Arellano, 1990; Huang \& Tsai, 2003; Sheorey, 2008) went beyond the English speaking boundaries. However, the cultural aspects where not taken into account as deeply as in this study. In fact, some aspects as parents support were included for the first time in this study as it is an important variable for the Latin-American culture (Antrop-González, Vélez, \& Garrett, 2003). A fourth phase would be convenient to visualize in other Latin American higher education institutions where English is also thought as a tool for academic success and better access to jobs. Thus, it would be suitable to apply in a different context: from a private to a public university and from students with wide development opportunities to students without that wide range of possibilities to expand their potentials. Changing these factors, results might be different and may be used to confirm or not that academically successful students are a better target population for going deeper into future Language Learning Strategies research projects.

\section{References}

Abu, W. (2003). Language learning strategies use in Palestine. Teaching English as a Second or Foreign Language, 7(2). Retrieved October 24, 2008, from http://www-writing.berkeley.edu/tesl-ej/ej26/ a3.html

Antrop-González, R., Vélez, W., \& Garrett, T. (2003). Where are the academically successful Puerto Rican students? Five success factors of high achieving Puerto Rican High School student. East Lansing, MI: The Julian Samora Research Institute, Michigan State University. (ERIC Document Reproduction Service No. ED50215)

Arellano, M. A. (1999). Application of learning strategies to improve student performance in a first level English course. Unpublished master's thesis, Tecnológico de Monterrey, Monterrey, Nuevo León, Mexico. 
Baker, C., \& Jones, S. (Eds.). (1998). Encyclopedia of bilingualism and bilingual education. Philadelphia, PA: Multilingual Matters.

Brockman, M. S., \& Russell, S. T. (2007). Academic success. building partnerships for youth. Retrieved August 10, 2007, from http://cals-cf.calsnet.arizona.edu/fcs/bpy/newsletters/bpy_ebulletin_issue06.html

Chamot, A. U. (2004). Issues in language learning strategy research and teaching. Electronic Journal of Foreign Language Teaching, 1(1), 14-26.

Cohen, A. (1998). Strategies in learning and using a second language. London: Longman.

Creswell, J. W., Plano, V., Gutmann, M. L., \& Hanson, W. E. (2003). Advanced mixed methods research designs. In A. Tashakkori \& C. Teddlie (Eds.), Handbook of mixed methods (pp. 209-240). Thousand Oaks: Sage.

Erzberger, C., \& Kelle, U. (2003). Making inferences in mixed methods: The rules of integration. In A. Tashakkori \& C. Teddlie (Eds.), Handbook of mixed methods (pp. 457-488). Thousand Oaks: Sage.

Graddol, D. (2000). The future of English. A guide to forecasting the popularity of the English language in the $21^{\text {st }}$. century. United Kingdom: The English Company Ltd.

Griffiths, C. (2004). Language learning strategies: Theory and research (Occasional Paper № 1). Auckland, New Zealand: School of Foundations Studies.
Haugen, E. (1972). The ecology of language. Stanford, CA: Stanford University Press.

Hernández, R., Fernández, C., \& Baptista, P. (2006). Metodología de la investigación (4th. ed.). Mexico: McGraw-Hill.

Huang, S. C. (2001). Effects of language learning strategy training on English learning. East Lansing, MI: The Julian Samora Research Institute, Michigan State University. (ERIC Document Reproduction Service No. ED 461 287)

Huang, S. C., \& Tsai, R. R. (2003). A comparison between high and low English proficiency learners' beliefs. East Lansing, MI: The Julian Samora Research Institute, Michigan State University. (ERIC Document Reproduction Service No. ED 482 579)

O'Malley, J. M., \& Chamot, A. U. (1990). Learning strategies in second language acquisition. Cambridge: Cambridge University Press.

Oxford, R. L. (1990). Language learning strategies. What every teacher should know. New York: Newbury House Publishers.

Sheorey, R. (2008, October). Language learning beliefs and learning strategies of Mexican EFL students. Annual Conference, Oklahoma Teachers of English to Speakers of other Language (OKTESOL), Oklahoma State University, U.S.A. 
